\title{
The Effect of Ca Ions for Bacteria
}

\author{
Hüseyin Kahraman* \\ Department of Biology, Turkey
}

*Corresponding author: Hüseyin Kahraman, Department of Biology, Faculty of Art and Sciences, Inonu University, Malatya 44280, Turkey

\begin{tabular}{|c|c|}
\hline ARTICLE INFO & ABSTRACT \\
\hline Received: 慧 November 27, 2019 & Citation: Hüseyin Kahraman. The Effect of Ca Ions for Bacteria. Biomed J Sci \& Tech Res \\
\hline Published: 猘 December 05, 2019 & 23(4)-2019. BJSTR. MS.ID.003929. \\
\hline
\end{tabular}

\section{Mini Review}

Calcium ions $\left(\mathrm{Ca}^{+2}\right)$ in eukaryotic cells have to; cell cycle, transport, mobility, gene expression and metabolism. Cells respond to various stimuli with transient changes in intracellular free $\mathrm{Ca}^{+2}$ concentrations. Indirect evidence indicates that $\mathrm{Ca}^{+2}$ also influence and such as spore formation, chemotaxis, heterosist differentiation, transport, and virulence. Many studies have shown that bacteria can maintain intracellular $\mathrm{Ca}^{+2}$ homeostasis. In addition, $\mathrm{Ca}^{+2}$; nitrogen starvation, environmental stress and metabolites of carbohydrate metabolism. According to studies with Escherichia coli, Bacillus subtilis and Pseudomonas aeruginosa, it has been shown that expression of hundreds of genes is regulated by extracellular $\mathrm{Ca}^{+2}$ changes. Processes affected by these changes include, for example, swarming, type III secretion, polysaccharide production, iron uptake, quinolone signaling, and general stress responses. Many studies demonstrate that $\mathrm{Ca}^{+2}$ play a regulatory role in the physiology of prokaryotes. The mutation analysis of EF-el protein (EfhP) from $P$. aeruginosa appears to be necessary for the maintenance of intracellular $\mathrm{Ca}^{+2}$ homeostasis. Specifically, adenylate kinase and fructose-bisphosphate-aldolase have also been detected in association with $\mathrm{Ca}^{+2}$ regulations in eukaryotic organisms.

Bacteria $\mathrm{Ca}^{+2}$ are; membrane-bound structures. Agrobacterium tumefaciens and Rhodospiriullum rubrum are very similar to the acidoccalcisomas first described in eukaryotic organisms. Asidocalcisom on; other elements such as $\mathrm{Ca}^{+2}, \mathrm{Na}^{+}, \mathrm{K}^{+}, \mathrm{Mg}^{+2}, \mathrm{Zn}^{+2}$ and phosphorus (P) are acidic organelles that serve as the main storage for $\mathrm{Ca}^{+2}$ in pyrophosphate (PPi) and polyphosphate (poly P) form. In eukaryotic microbes, acidocalcisomes function in $\mathrm{P}$ metabolism, $\mathrm{Ca}^{+2}$ homeostasis, maintenance of intracellular $\mathrm{pH}$ and osmo regulation. Prokaryotic acidocalcisomes are very similar to eukaryotic structures that contain $\mathrm{H}^{+}$-ATPase carriers and vacuum proton translocated pyrophosphatase responsible for their acidification. The ability of $R$. rubrum acidocalcisomes to store $\mathrm{Ca}^{+2}$ could be demonstrated by X-ray microanalysis when bacterial cells were grown at $100 \mathrm{mM} \mathrm{CaCl}_{2}$. As a result, it has been suggested that acidocalcisomes may be involved in $\mathrm{Ca}^{+2}$ homeostasis in some bacteria. In Gram (-) bacteria, this region includes the region between the periplasmic space, the outer membrane and the cytoplasmic membrane.

The presence of this compartment was also detected in Gram (+) bacteria. X-ray mapping and electron loss spectroscopy showed that high concentrations of $\mathrm{Ca}^{+2}$ were related to the cellular structure of E. coli. The periplasma contains oligosaccharides and anionic proteins that may play a role in the storage of $\mathrm{Ca}^{+2}$ in this compartment. According to a study, the outer membrane and periplasm first serve as a barrier to $\mathrm{Ca}^{+2}$ entries. Secondly, it is thought to play a very important role by buffering and storing $\mathrm{Ca}^{+2}$. By targeting the photoprotein aequorin using the $\mathrm{N}$-terminal OmpT signal sequence, the periplasma has been shown to store $\mathrm{Ca}^{+2}$ in the periplasm of living E. coli cells ranging from 3-6-fold relative to the external environment. These results show us that bacterial cells; it supports our idea that it may have the ability to regulate $\mathrm{Ca}^{+2}$ concentrations by using different mechanisms within cellular separate compartments. However, the answer to this question is unknown today; to what extent do micro-regions in bacteria contribute to $\mathrm{Ca}^{+2}$ homeostasis? [1] this is one of the pending questions.

$\mathrm{Ca}^{+2}$ are a well-known signal molecule that regulates a number of basic processes in eukaryotes. Abnormalities in cellular $\mathrm{Ca}^{+2}$ regulations have been associated with bacterial infections such 
as cystic fibrosis (CF) and endocarditic. All evidence; shows that intracellular and extracellular $\mathrm{Ca}^{+2}$ balances in a host can be a clue to opportunistic pathogenic bacteria and trigger their virulence. In addition, $\mathrm{Ca}^{+2}$ in prokaryotes; spore formation, mobility, cell differentiation, transport and virulence. It has also been shown that $\mathrm{Ca}^{+2}$ regulate bacterial gene expression and its regulatory role in prokaryotes. There is also increasing evidence that $\mathrm{Ca}^{+2}$ play a signaling role in the regulation of cellular $\mathrm{Ca}^{+2}$ in prokaryotes. The intracellular $\mathrm{Ca}^{+2}$ of various bacteria such as $E$. coli, Propionibacterium acnes, Streptococcus pneumoniae, B. subtilis and Cyanobacteria were maintained at $\mu \mathrm{M}$ levels and the $\mathrm{Ca}^{+2}$ effect was shown in response to environmental and physiological conditions. Such responses; $\mathrm{Ca}^{+2}$ regulated bacteria may play a key role in physiology and virulence. Some studies show that bacteria control $\left[\mathrm{Ca}^{+2}\right]$ using various mechanisms to transport or chelate $\mathrm{Ca}^{+2}$. Some types of $\mathrm{Ca}^{+2}$ transport systems have been described in prokaryotes:

\section{a) Gradient driven $\mathrm{Ca}^{+2}$ heat exchangers, \\ b) ATPase \\ c) Non-protein polyhydroxybutyratepolyphosphate (PHB- PP) channels.}

It is also thought that $\mathrm{Ca}^{+2}$ modifiers are identified in some bacterial strains and serve as a main mechanism for $\mathrm{Ca}^{+2}$ transports in prokaryotes. These are low affinity $\mathrm{Ca}^{+2}$ carriers that used the stored energy of the electrochemical gradient of ions. They can work in both directions depending on the gradient. P. aeruginosa is an opportunistic human pathogen and is known to be one of the main causes of nosocomial infections and severe chronic infections in endocarditis and CF patients. Previously, growth in high $\mathrm{Ca}^{+2}$ has been shown to increase the formation of $P$. aeruginosa biofilm and induce biosynthesis of many secreted virulence factors including alginate, extracellular proteases and pyocyanin [2]. $\mathrm{Ca}^{+2}$ levels include hydrolytic modulation of the hydrolytic enzyme in Pectobacterium carotovorum produced in V. cholerae. In addition, $\mathrm{Ca}^{+2}$ in animal and plant hosts; as a secondary messenger, it regulates defense responses based on regulatory systems. Calcium, magnesium and iron are known to be involved in the process of $X$. fastidiosa infection.

However, it has also been suggested that in some cases (e.g. $\mathrm{Ca}^{+2}$ and $\mathrm{Mg}^{+2}$ ), these elements are non-specific and act as bridges of adhesion between negatively charged bacterial cells and xylem vessels. The presence of $\mathrm{Ca}^{+2}$; increases biofilm formation, cell binding and mobility under in vitro conditions. $\mathrm{Ca}^{+2}$ levels also affect biofilm production. Bivalent cations containing $\mathrm{Ca}^{+2}$ and $\mathrm{Mg}^{+2}$ have previously been shown to play a role in the formation of biofilm by different bacteria. In Erwinia carotovora, high $\mathrm{Ca}^{+2}$ levels suppress the expression of PehA, an endopoliglaklacronase, one of the major virulence determinants. The opposite effect, ie increase in virulence, was observed in P. aeruginosa. Here, with the addition of $\mathrm{Ca}^{+2}$, increased production of extracellular proteases and increased expression of alginate biosynthetic genes, which are the main components of extracellular matrix, also affected the increase of biofilm thickness. $X$. fastidiosa has been shown to play a role in the regulation of biofilm formation, its effect on the cell surface and twitch mobility. Some studies; it also shows that the addition of $\mathrm{Ca}^{+2}$ significantly increases the surface binding strength of the cells. In addition to the "bridging" effect that may occur with $\mathrm{Ca}^{+2}$, it has been shown that in addition to the effect of $\mathrm{Ca}^{+2}$ on biofilm and movement, a metabolic dependent effect may be responsible [3].

In addition to their role in biofilm matrix stability, $\mathrm{Ca}^{+2}$ can also affect bacterial gene expression. In eukaryotic cells, $\mathrm{Ca}^{+2}$ is an important signaling molecule and can play a regulatory role in bacteria. Many bacteria; P. aeruginosa PA4107 also includes genes for calmodulin-like proteins with characteristic EF hand motifs, including PlcR, possibly shown to bind $\mathrm{Ca}^{+2}$. The secretion and stability of some extracellular proteins in $P$. aeruginosa are influenced by $\mathrm{Ca}^{+2}$. The toxins secreted by the Type III secretion system are suppressed by $\mathrm{Ca}^{+2}$. The amounts of extracellular elastase (LasB) and LasA secreted by Type II secretion increase in the presence of additional $\mathrm{Ca}^{+2}$. It is also known that $\mathrm{Ca}^{+2}$ affect the biofilm structure. Interestingly, added $\mathrm{Ca}^{+2}$ has been shown to cause biofilms of mucoid P. aeruginosa FRD1, which is 10 to 20 -fold thicker than non- $\mathrm{Ca}^{+2}$ added biofilms. The amounts of extracellular proteases were increased in $\mathrm{Ca}^{+2}$ modified biofilms and it was also found that the proteases were housed in the $\mathrm{Ca}^{+2}$ enhanced alginate matrix [4]. To date, salt and glucose have always been studied and studied in health-related diets. As a result of this information, it should be remembered that $\mathrm{Ca}^{+2}$ diets may also be effective in understanding and reducing the effects of microorganisms.

\section{Acknowledgement}

None.

\section{Conflict of Interest}

No conflict of interest.

\section{References}

1. DC Domíngueza, M Guragain, M Patrauchan (2015) Calcium binding proteins and calcium signaling in prokaryotes. Cell Calcium 57(3): 151165.

2. M Guragain, DL Lenaburg, FS Moore, I Reutlinger, MA Patrauchan (2013) Calcium homeostasis in Pseudomonas aeruginosa requires multiple transporters and modulates swarming motility. Cell Calcium 54(5): 350361.

3. LF Cruz, PA Cobine, L De La Fuente (2012) Calcium increases Xylella fastidiosa surface attachment, biofilm formation, and twitching motility. Applied and Environmental Microbiology 78 (5): 1321-1331.

4. S Sarkisova, MA Patrauchan, D Berglund, DE Nivens, MJ Franklin (2005) Calcium-induced virulence factors associated with the extracellular matrix of mucoid Pseudomonas aeruginosa biofilms. Journal of Bacteriology 187(13): 4327-4337. 
ISSN: 2574-1241

DOI: 10.26717/BJSTR.2019.23.003929

Hüseyin Kahraman. Biomed J Sci \& Tech Res

(C) (P) This work is licensed under Creative BY Commons Attribution 4.0 License

Submission Link: https://biomedres.us/submit-manuscript.php

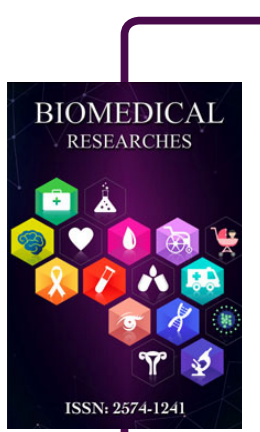

Assets of Publishing with us

- Global archiving of articles

- Immediate, unrestricted online access

- Rigorous Peer Review Process

- Authors Retain Copyrights

- Unique DOI for all articles

https://biomedres.us/ 